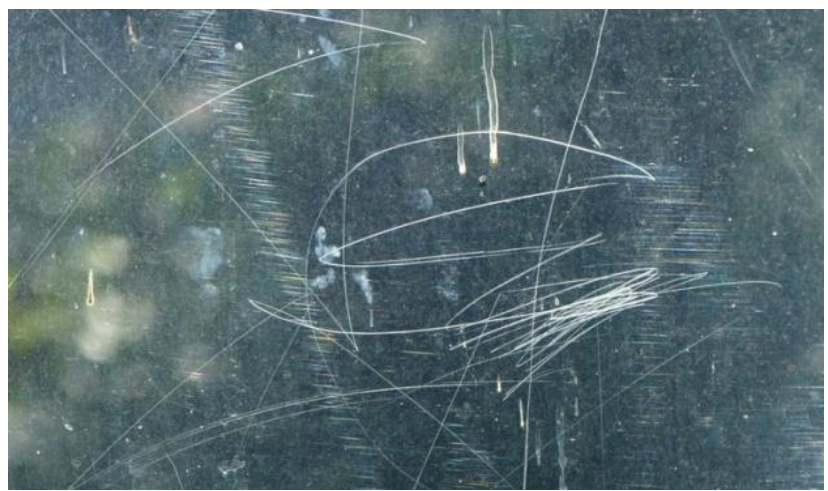

\title{
Ranhura na vidraça
}

Eduardo Guimarães

ORCID: https://orcid.org/0000-0002-7066-2814

Estridente rangido

desagrado dissonante

punhal cravado

no olhar

\section{Cemitério}

arame farpado

urubus

sentinelas

\section{Cério}

e não sério

não se é

senão

o não ser

a história

sem volta

mesmo que violenta

Necrotério

ranhura

desalento

Problemas de memória

cólica

aborto imotivado

fraqueza muscular

Resistimos

porque somos

por viver

a vida 
O vidro não quebra

só não deixa ver

inútil

de tantos arranhões

E vemos

e continuamos vendo

e vivendo

a desistência mataria

O corvo

sobre que corpos putrefeitos

voeja messiânico

desejoso do mal cheiro que produz

$\mathrm{O}$ corte

vontade palpitante de morte

mata um dia quem o desferiu

A ranhura não cessa

engole o próprio punhal

como seu maior desejo

O caminho único é o caminho do penhasco

Só não cai

quem encontra

outras veredas

Cicatrizes

são o que a vida

nos dá a viver 
Eduardo Guimarães nasceu em Prata - MG, tendo ido viver em Uberaba, onde se formou em Letras. É poeta, linguista, e professor da Unicamp. Doutorou-se em Letras pela USP. Publicou Cidade; Corte; Cicatriz (poesia); e Texto e Argumentação; Semântica do Acontecimento; História da Semântica, Sujeito, Sentido e Gramática no Brasil; Análise de Texto; Semântica: Enunciação e Sentido, entre outros (Ciências da Linguagem). E-mail de contato: eduardo@unicamp.br.

Em um dos poemas de Cicatriz está:

Nada que me venha /é indiferente. / Como saber o que chega / Se vai ou se some I na fumaça cinza / que cobre a cidade? 


\section{Para citar essa obra:}

GUIMARÃES, Eduardo. Ranhuras na Vidraça In: RUA [online]. Volume 27, número 2 - p. 483-485 - e-ISSN 2179-9911 - novembro/2021. Consultada no Portal Labeurb - Revista do Laboratório de Estudos Urbanos do Núcleo de Desenvolvimento da Criatividade.

http://www.labeurb.unicamp.br/rua/

\section{Laboratório de Estudos Urbanos - LABEURB}

Núcleo de Desenvolvimento da Criatividade - NUDECRI

Universidade Estadual de Campinas - UNICAMP

http://www.labeurb.unicamp.br/

\section{Endereço:}

LABEURB - LABORATÓRIO DE ESTUDOS URBANOS

UNICAMP/COCEN / NUDECRI

CAIXA POSTAL 6166

Campinas/SP - Brasil

CEP 13083-892

Fone/ Fax: (19) 3521-7900

Contato: http://www.labeurb.unicamp.br/contato 